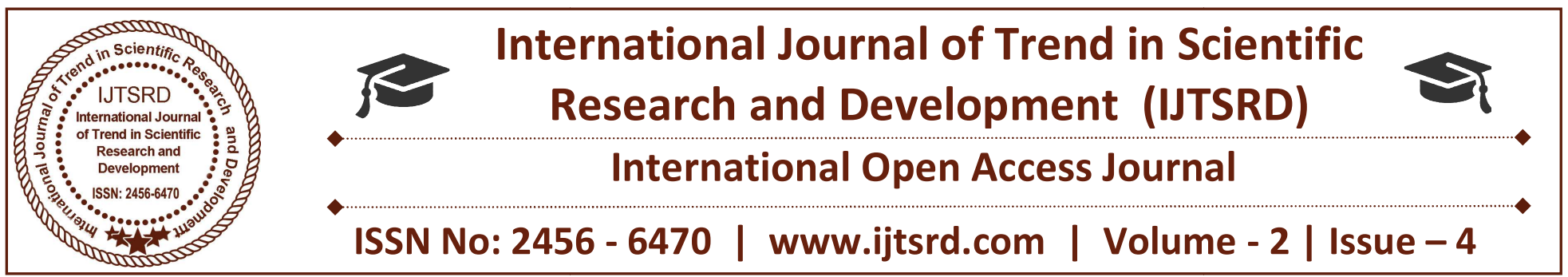

\title{
A Research Paper on Porous Asphalt Pavement
}

\author{
Vaibhav Patil ${ }^{1}$, Pooja Patil ${ }^{1}$, Jayashree Patil ${ }^{1}$, Mrunal Patil ${ }^{1}$, Kirtee Sawant ${ }^{1}$, Mr. S. P. Patil ${ }^{2}$ \\ ${ }^{1}$ B. E. Student, ${ }^{2}$ Faculty \\ Department of Civil Engineering, Padmabhooshan Vasantraodada Patil Institute of Technology, \\ Budhgaon, Maharashtra, India
}

\begin{abstract}
The aim of this study is to recharge ground water to underplaying aquifers and reduce risk of flood condition. Porous asphalt pavement is an alternative technology that differs from traditional asphalt pavement designs, that the pavement permits fluid to pass freely through it. Porous asphalt pavement also reduces and control surface runoff of surrounding area. This technique also can be used as additional way of storm water management. The past few studies suggests that, porous asphalt pavement intended to be used for parking lots, storm water management, water quality treatment, peak flow reduction and noise control. The research has focused on improving quality and quantity of ground water. This study includes model making and checking performance of that constructed pavement model. Study investigates performance of aggregates and porous asphalt used in projects, such as properties of aggregates like impact value, crushing value, specific gravity, abrasion test. Tests performance on porous asphalt includes ductility test, stripping value test and penetration test. Study includes sample making of various proportion of asphalt and aggregates. Total 9 samples were made to check which sample gives best performance as per the requirement. Out of 9 samples, $6 \%$ asphalt with $10 \mathrm{~mm}$ aggregate + grit sample gives required performance.
\end{abstract}

Keywords: Crushing strength, Impact value, Ductility, Penetration, stripping value

\section{INTRODUCTION}

Porous asphalt (PA) also namely open graded asphalt has been use as a wearing surface since the 1950s. Its first major use in Australia was about 1973 and in
Japan was about 1987. Porous asphalt is an innovative road surfacing technology which allows water to enter into the asphalt mixes beyond its continuous air voids, several studies are quantified high removal rates of total suspended solids, metals, oils, and grease, as well as moderate removal for phosphorus, from using porous asphalt pavement. Porous asphalt pavements with stone reservoirs are a multifunctional, low impact development technology that integrate ecological and environmental goals for a site with land development goals, reducing the net environmental impact for a project.

Not only do they provide a strong pavement surface for parking, walkways, trails and roadways, they are designed to manage and treat storm water runoff. With proper design and installation, porous asphalt pavements can provide a cost-effective solution for storm water management in an environmentally friendly way.

Porosity of the asphalt mastic is usually between 15 and 20 percent. The sub-base layers may include water storage systems or normal pavement structure as used also under impermeable surfaces (overlay structure). Functionality of the porous asphalt pavement is the same as that of other pervious pavements. Storm water infiltrates to soil through pavement layer and it reduces ponding and need of sewer systems. Effects on friction and hydrological systems are positive. Additional benefits are also noise reduction, which is desirable feature in residential or high trafficked area and better visibility when there is hydroplaning, spraying and light reflection results. This proven concept of building porous asphalt pavements was declared Outstanding 
Engineering project in 2000 by the American Society of Civil Engineers.

\section{LITERATURE REVIEW}

1) Indian Road Congress Journal, "Indian Highways"

The Jaipur Development Authority (JDA) had planned to construct a conventional dense graded asphalt parking lot at the Gandhi Nagar Railway Station in Jaipur. It was decided to include an experimental porous asphalt area (about $85 \mathrm{~m}$ by $4 \mathrm{~m}$ ) as part of the large parking lot. It is believed to be the first ever porous asphalt pavement constructed in India for rainwater harvesting. According to the 2004 data of CGWB, for every 125 units of ground water being taken out in Jaipur, only 100 units are replenished by rain. It is estimated that the ground water level in Jaipur is falling at the rate of about one meter every year.

\section{2) Danish Road Institute}

A brief historic summary of the development of porous asphalt is provided by Kraemer at the opening of the European Conference on Porous Asphalt in Madrid in 1997 [17]. Originally developed to prevent skidding on wet pavements in the thirties in the US porous asphalt was ready for general applications on highways and airports in the seventies. This was the basis for the European development of porous asphalt in the early eighties based on the research at the University of Cantabria where a mix-design method for porous asphalt was established. In 1985 the operational use on motorways and major roads began and a rapid development took place especially when the noise reducing benefits was recognised.

\section{3) University Of New Hampshire Stormwater Center Journal(UNHSC)}

This specification is intended to be used for porous asphalt pavement in parking lot applications. Stormwater management functions of porous asphalt installations include water quality treatment, peak flow reduction, storm volume reduction via groundwater recharge, and increased hydrograph time lag. This specification is intended for a cold climate application based upon the field experience at the UNHSC porous asphalt parking lot located in Durham, New Hampshire, however the specification can be adapted to projects elsewhere provided that selection of materials and system design reflects local conditions, constraints, and objectives.

\section{EXPERIMENTAL PROGRAM}

Experiments were conducted on porous asphalt and aggregate. Samples are made using various proportions $(4 \%, 6 \%, 7 \%)$ of porous asphalt of the total weight of aggregate. Out of these 9 samples, we choose sample which gave better and controlled performance.

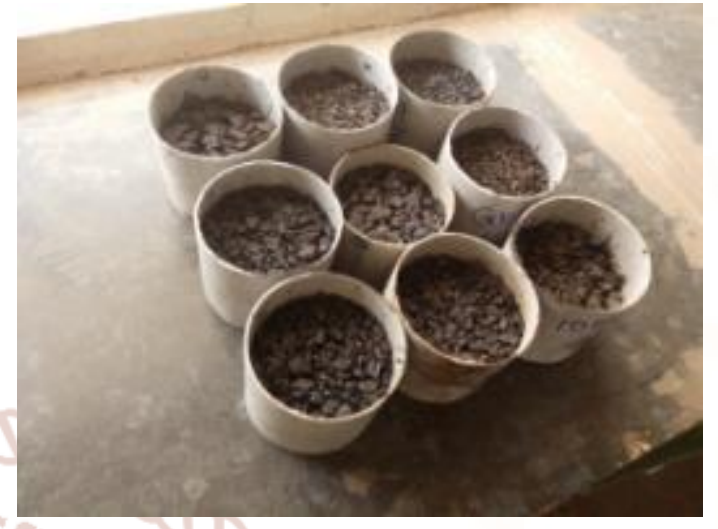

IV. OBJECTIVES OF THE RESEARCH

To reduce risk of flooding situations and increase safety of drivers during wet weather.

Recharges ground water to Underlaying Aquifers and improving water quality by filtering pollutants in the substrata layers.

To Reduce splash and spray from Travelling vehicle, Reduced Roadway noise.

\section{AMATERIALS USED}

\section{Porous Asphalt}

Polymer Modified Bitumen grade 40 was used in the design mix. The $6 \%$ asphalt was added for the final pavement model.

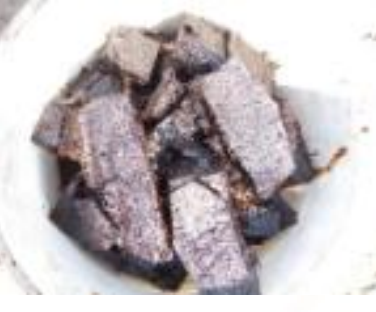

Table 1: Properties of Porous Asphalt

\begin{tabular}{|l|l|}
\hline \multicolumn{1}{|c|}{ Properties } & \multicolumn{1}{|c|}{$\begin{array}{c}\text { Observed } \\
\text { values }\end{array}$} \\
\hline Specific Gravity & 0.882 \\
\hline Ductility & $3.5 \mathrm{~cm}$ \\
\hline Penetration Value & $30-50 \mathrm{~mm}$ \\
\hline Stripping value & $1.72 \%$ \\
\hline
\end{tabular}

\section{Coarse Aggregate}

1. For chocker course, aggregate passed through $16 \mathrm{~mm}$ and retained on $12.5 \mathrm{~mm}$ sieve size used.

2. For top wearing course, aggregate passed through $12.5 \mathrm{~mm}$ and retained on $10 \mathrm{~mm}$ sieve size and grit 
International Journal of Trend in Scientific Research and Development (IJTSRD) ISSN: 2456-6470

used for strength and controlled performance of pavement.

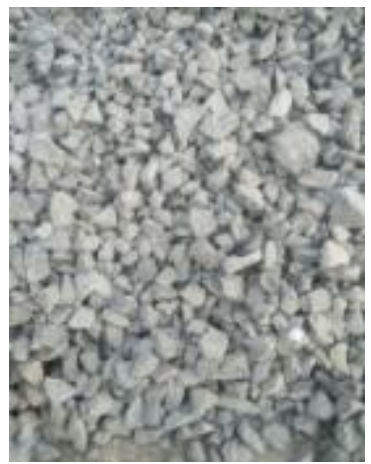

Table 2: Properties of Coarse aggregate

\begin{tabular}{|l|l|}
\hline \multicolumn{1}{|c|}{ Properties } & \multicolumn{1}{|c|}{$\begin{array}{c}\text { Observed Impact } \\
\text { values (\%) }\end{array}$} \\
\hline $\begin{array}{l}\text { Passing through } 16 \mathrm{~mm} \& \\
\text { retained on } 12.5 \mathrm{~mm}\end{array}$ & 5.1 \\
\hline $\begin{array}{l}\text { Passing through } 12.5 \mathrm{~mm} \& \\
\text { retained on } 10 \mathrm{~mm}\end{array}$ & 10.52 \\
\hline
\end{tabular}

According to IS-2386 (Part IV) Aggregate impact value shall not exceed $45 \%$ for aggregate used in base course \& intermediate course and $30 \%$ for wearing surfaces.

\section{Table 3}

\begin{tabular}{|l|c|}
\hline \multicolumn{1}{|c|}{ Properties } & \multicolumn{1}{|c|}{$\begin{array}{c}\text { Observe Crushing } \\
\text { values (\%) }\end{array}$} \\
\hline $\begin{array}{l}\text { Passing through } 16 \mathrm{~mm} \& \\
\text { retained on } 12.5 \mathrm{~mm}\end{array}$ & 15.47 \\
\hline $\begin{array}{l}\text { Passing through } \\
12.5 \mathrm{~mm} \& \text { retained on } \\
10 \mathrm{~mm}\end{array}$ & 17.79 \\
\hline
\end{tabular}

According to IS-2386 (Part IV) Aggregate crushing value shall not exceed $45 \%$ for aggregate used in base course \& intermediate course and $30 \%$ for wearing surfaces.

\section{Table 4}

\begin{tabular}{|l|l|}
\hline \multicolumn{1}{|c|}{ Properties } & \multicolumn{1}{|c|}{$\begin{array}{c}\text { Observed Abrasion } \\
\text { values (\%) }\end{array}$} \\
\hline $\begin{array}{l}\text { Passing through } 16 \mathrm{~mm} \\
\text { \& retained on } 12.5 \mathrm{~mm}\end{array}$ & 3.48 \\
\hline $\begin{array}{l}\text { Passing through } 12 \mathrm{~mm} \\
\text { \& retained on } 10 \mathrm{~mm}\end{array}$ & 4.24 \\
\hline
\end{tabular}

Abrasion value of aggregate forpavement is upto $20 \%$. Hence above samples should be useful for road surfacing.

\section{$>$ Gravel}

Gravel passed through $50 \mathrm{~mm}$ and retained on $40 \mathrm{~mm}$ sieve size for the reservoir bed.

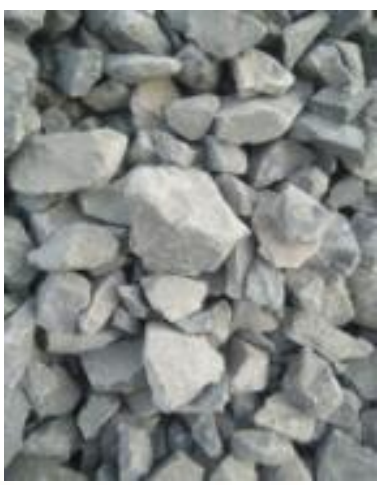

Table 5: Properties of Gravels

\begin{tabular}{|l|l|}
\hline \multicolumn{1}{|c|}{ Properties } & \multicolumn{1}{|c|}{$\begin{array}{c}\text { Observed } \\
\text { values }\end{array}$} \\
\hline $\begin{array}{l}\text { Passing through 50mm\& retained } \\
\text { on 40mm (Impact value) }\end{array}$ & $1.96 \%$ \\
\hline $\begin{array}{l}\text { Passing through 50mm\& retained } \\
\text { on 40mm (Crushing Value) }\end{array}$ & $11.59 \%$ \\
\hline $\begin{array}{l}\text { Passing through 50mm \& retained } \\
\text { on 40mm (Abrasion value) }\end{array}$ & $1.44 \%$ \\
\hline Specific gravity & 3.167 \\
\hline Water Absorption & $2.183 \%$ \\
\hline
\end{tabular}

\section{Geotextile sheet}

Pervious and impervious layer of geotextile sheets are used above the natural ground strata. We used $300 \mathrm{gsm}$ geotextile sheet for the final model above the soil layer.

\section{Soil}

Table 6: Properties of Soil

\begin{tabular}{|l|l|}
\hline \multicolumn{1}{|c|}{ Properties } & \multicolumn{1}{|c|}{$\begin{array}{c}\text { Observed } \\
\text { values }\end{array}$} \\
\hline Water Content & $12.98 \%$ \\
\hline Specific gravity & 2.34 \\
\hline Type of sand & medium \\
\hline Coefficient of permeability & $0.0219 \mathrm{~cm} / \mathrm{s}$ \\
\hline
\end{tabular}

\section{MIX DESIGN OF SAMPLES}

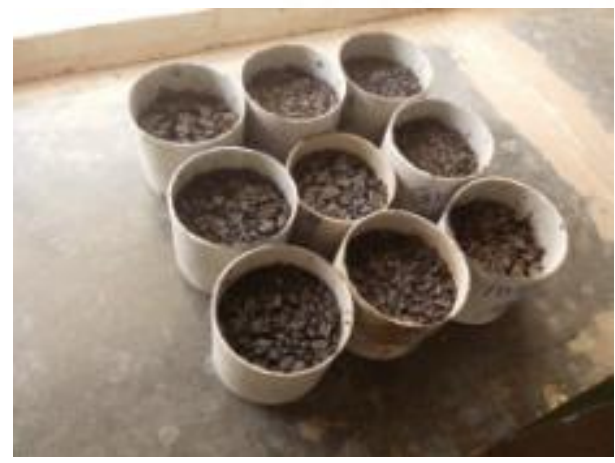


Table 7: Mix design of sample for top layer

The 9 samples are made with using combinations of $10 \mathrm{~mm}$ aggregate and grit. The samples are casted in PVC pipe with constant diameter and thickness.

\begin{tabular}{|c|c|c|c|}
\hline Sample & $\begin{array}{l}\text { Weight of aggregate } \\
\text { (gm) }\end{array}$ & $\begin{array}{c}\text { Percent of Porous Asphalt } \\
\text { added (\%) }\end{array}$ & $\begin{array}{l}\text { Weight of Porous } \\
\text { Asphalt (gm) }\end{array}$ \\
\hline \multirow{3}{*}{$\begin{array}{l}\text { Aggregate } \\
\text { retained on } \\
10 \mathrm{~mm}\end{array}$} & 960 & 7 & 67.2 \\
\hline & 960 & 6 & 57.6 \\
\hline & 960 & 4 & 38.4 \\
\hline \multirow{3}{*}{ Grit } & 913 & 7 & 63.91 \\
\hline & 913 & 6 & 54.78 \\
\hline & 913 & 4 & 36.52 \\
\hline \multirow{3}{*}{$\begin{array}{l}\text { Retained } \\
\text { on } \\
10 \mathrm{~mm}+\text { Grit }\end{array}$} & 965 & 7 & 67.55 \\
\hline & 965 & 6 & 57.9 \\
\hline & 965 & $4 \square$ & 38.6 \\
\hline
\end{tabular}

The samples are made with the combination, 3 samples are made with only $10 \mathrm{~mm}$ retain aggregate size, 3 samples are made with only grit, and other 3 samples are made with combination of these two.

Table 8: Determination of time

The 9 samples are made, after casting determine the time, for passing the same amount of water from each sample. The time required for passing the water through each sample is given below in the table.

\begin{tabular}{|c|c|c|}
\hline Sample & $\begin{array}{l}\text { Percent of Porous } \\
\text { Asphalt added }(\%)\end{array}$ & $\begin{array}{l}\text { Time required for pass the } \\
\text { same amount of water in (sec) }\end{array}$ \\
\hline \multirow{3}{*}{$\begin{array}{l}\text { Aggregate } \\
\text { retained on } \\
10 \mathrm{~mm}\end{array}$} & nternation & 28.2 ourna \\
\hline & 6 & 30 \\
\hline & 401 tremion & 27.5 entutic \\
\hline \multirow{3}{*}{ Grit } & 7 & 0 \\
\hline & 6 & 33.6 \\
\hline & DevelO & 34.9 \\
\hline \multirow{3}{*}{$\begin{array}{l}\text { Retained on } \\
10 \mathrm{~mm} \\
\text { Grit }\end{array}$} & 7 & $=$ \\
\hline & 60 & $32.1 / 70$ \\
\hline & 4 & $0^{\circ}$ \\
\hline
\end{tabular}

\section{Graph No 1}

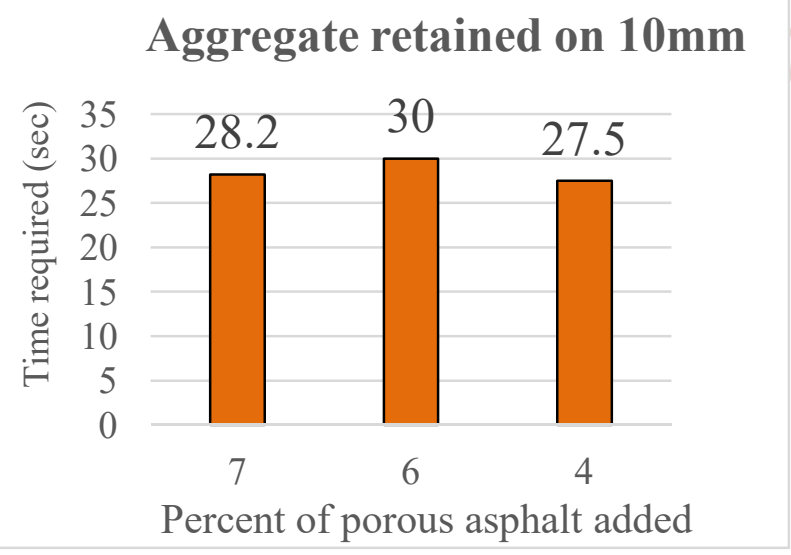

Graph No 2

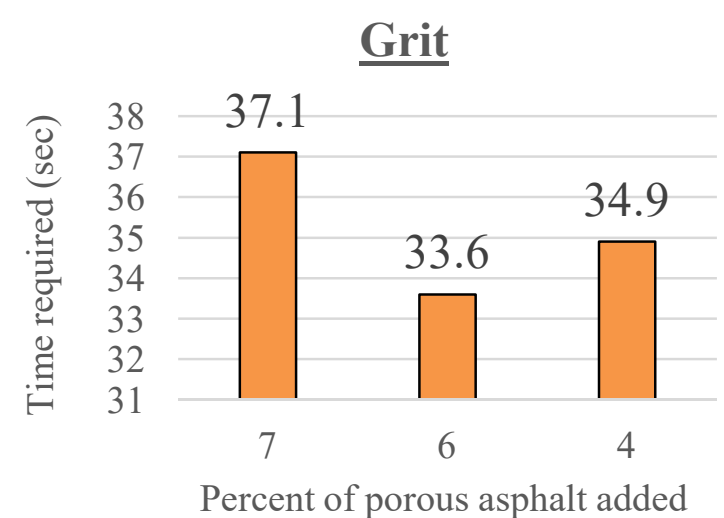




\section{Graph No 3}

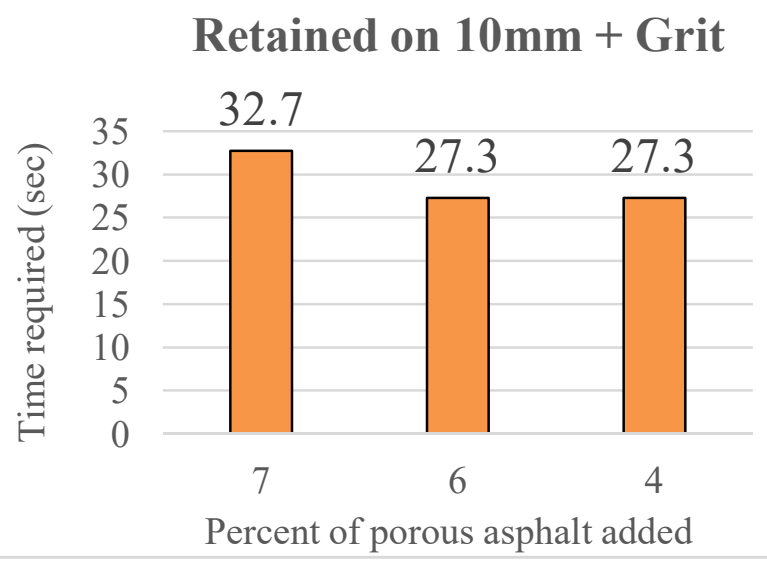

From above table and graphs it is observed that, the sample made with $10 \mathrm{~mm}$ size aggregate with grit give better and controlled performance instead of only $10 \mathrm{~mm}$ size or only grit models. We chose $6 \%$ asphalt content $+10 \mathrm{mmsize}$ with grit sample mix for the final model for the top wearing course.

\section{MIX DESIGN OF CONSTRUCTED PAVEMENT}

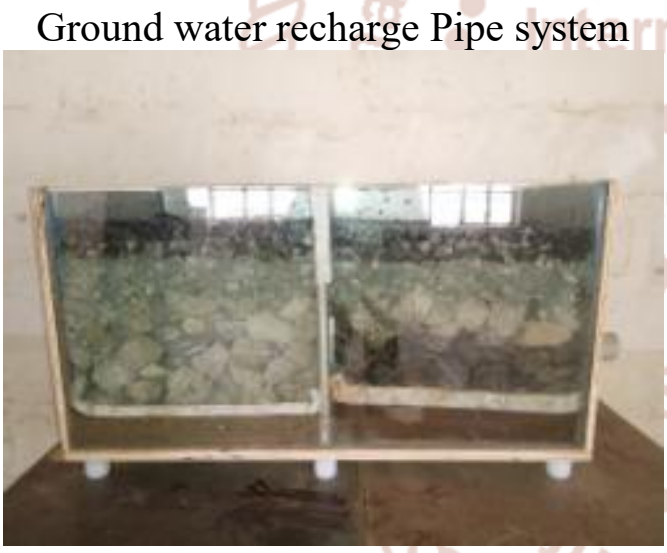

\section{$>$ UNCOMPACTED SUBGRADE}

These is natural ground strata. This layer is uncompacted only digging action is done on this layer at the time of large site taken in consideration. For model, we take layer thickness of these layer is $5 \mathrm{~mm}$ and for the pipe system portion we give the slight slope for drainage purpose.

\section{GEOTEXTILE SHEET LAYER}

For ground water recharge portion, we use non-oven pervious geotextile sheet for infiltration of water below ground.

For pipe system portion we use non-oven laminated geotextile sheet which is impervious in nature.
STONE RESEVOIR COURSE

The function of the stone reservoir course is to temporarily store rainwater which percolates slowly into the natural subgrade below. We take the aggregate size for this layer is aggregate passing through $50 \mathrm{~mm}$ sieve and retain on $40 \mathrm{~mm}$ sieve. Thickness provided for this layer is $23 \mathrm{~cm}$.Perforated pipe is used for the pipe system portion for the drainage.

\section{STONE CHOKING COURSE}

The stone choking layer is placed on the stone reservoir course so as to fill and level its open large surface voids and to make it stable and smooth for asphalt paver. It was placed in $50 \mathrm{~mm}$ (2 inches) thick layer and compacted well with an 8-ton steel wheel roller in static mode only until a smooth surface was obtained for paving above it. Aggregate used for this layer is $16 \mathrm{~mm}$ sieve passing and $12.5 \mathrm{~mm}$ retain on sieve.

\section{POROUS ASPHALT WEARING COURSE}

These is open graded and top asphalt layer of these pavement. The layer thickness provided for this layer is $60 \mathrm{~mm}$. The aggregate used for these layer as same as choking course layer. The asphalt used for this layer is $6 \%$ by weight of total mix of aggregate. The thickness ranges of layers are given in Indian Roads Congress Journal, "Indian Highways", Vol. 42 No. 3, March 2014].

\section{CONCLUSION}

$>$ Constructed pavement model has a negligible surface runoff hence it reduces the surface runoff and increase the safety of drivers and vehicles in wet weather, and also reduces drainage clogging problems.

In rainy season, the water is infiltrates from porous asphalt pavement and increases the water table level below the ground, we can use this water for various purposes or we can store this water for future use.

From this pavement the various type of pollutants are also infiltrates like oil, petrol liquid pollutants, because of this increases safety of vehicles and decreases possibility of accidents.

Porous asphalt pavement absorbs the noise from roadway vehicles and reduces the flash and spray to the vehicles in wet weather with infiltration property. 


\section{REFERANCES}

1. Akihiro Moriyosh, Toshiro Jin, TakaakiNkai and Hiroshi Ishikawa (2013), Construction and Building Materials, Evaluation methods for porous asphalt pavement in service for fourteen years Vol.42, pages 190-195.

2. Robert M Roseen, Thomas P Ballestro, James J Houle, Joshua F Briggs and Kristopher M Houle(2012),Journal of environmental quality and hydrologic performance of a porous asphalt pavement as a storm water treatment strategy in a cold climate vol.138engineering, water

3. Mohd Rosli Mohd Hasan,Jia Yih Eng,Moer Othman Hamzah and J. L. $m$ Voskuilen (2013),Construction and Building Materials, The effects of breakpoint location and normal maximum aggregate size on porous asphalt properties vol 44, pages $360-367$

4. Glanluca Dell Acgu,Moro kur,Raffaelo Mauro and Francesca Russo (2012), procedia-Social and Behaviour Sciences, Freeway crashes in wet weather; the comparative influence of porous and conventional asphalt surfacing Vol 54, pages 618627.

5. Kandhal, P.S. A Revolutionary Technique of Rainwater Harvesting Integrated into the Design of Buildings and Parking Lots. Water Digest Magazine, March-April 2011, New Delhi, India.
6. Kandhal, P. S. Design, Construction and Performance of Open-Graded Asphalt Friction Courses. National Asphalt Pavement Association, Information Series IS-115, May 2002.

7. Kandhal, P.S. and R.B. Mallick. Open-Graded Friction Course: State of the Practice. Transportation Research Board, Transportation Research Circular Number E-C005, December 1998.

8. Roberts, F.L., P.S. Kandhal, E.R. Brown, D.Y. Lee, and T.W. Kennedy. Hot Mix Asphalt Materials, Mixture Design and Construction. NAPA Education Foundation, Lanham, Maryland, Second Edition, 1996.

9. Kandhal, P.S. Role of Permeable Pavement in Groundwater Recharge. Presentation at the Rajasthan State Workshop on Water Conservation: Issues and Challenges. Held in Jaipur by the Centre for Science and Environment (CSE), 7 February 2013.

10. Book of Transportation engineering, Electrotech publication.

11. September 2004, Stormwater Best Management Design Guide: Volume 1 General Considerations, Office of Research and Development, EPA/600/R04/121, Washington, D.C.

12. Vermont Agency of Transportation, 2006, 2006 Standard Specifications for Construction Book, Division 700, Section 708, Montpelier, VT. 